\title{
THE USE OF INDONESIAN ENGLISH CODE MIXING ON INSTAGRAM CAPTIONS
}

\author{
Bani Lisa Nuraeni ${ }^{1}$, Mochammad Zhafran Farid ${ }^{2}$ \\ ${ }^{1}$ IKIP Siliwangi \\ ${ }^{2}$ IKIP Siliwangi \\ ${ }^{1}$ banilisanuraeni@gmail.com, ${ }^{2}$ zhafranfarid@gmail.com
}

\begin{abstract}
Recent studies on intrasentential code-switching or code mixing (CM) show the functional separation of two languages to be a legitimate, highly structured bilingual communicative device with its own syntactic and sociolinguistic constraints.This research investigates the use of code mixing on instagram. The study aims to find out kind of code mixing used on Instagram users in their caption and to find out how many code mixing code used by instagram users in their caption. This research applies descriptive qualitative method. The data of this research are Indonesian - English code mixing on Indonesian Instagram users posting and the information of the reasons of using code mixing. The data are taken from the Indonesian Instagram users posting. The data are analyzed based on the linguistic form of code mixing by Suwito's theory and the reasons of code mixing by Hockett's theory.
\end{abstract}

Keyword: Code Mixing, Instagram, Linguistic form

\section{INTRODUCTION}

In communication, the relation between language and society cannot be separated. The study about the relation of language and society is called sociolinguistics. According to (Wardhaugh, 1986b) sociolinguistics is concerned with investigating the relationship between language and society with the goal being a better understanding of the structure of language and of how languages function in communication; the equivalent goal in the sociology of language is trying to discover how social structure can be better understood through the study of language, e.g., how certain linguistic features serve to characterize particular social arrangement.

Based on (Weinreich, 1953) said that two or more languages will be said to be in contact if they are used alternatively by the same person. When a common second language is learned and used by a group of people whether immigrants or by virtue of the introduction of a new language to a resident population they often find themselves introducing secondlanguage lexical items into conversation with fellow bilinguals in their original first language. Such items, referred to by Weinreich as nonce borrowings according to (Weinreich, 1968) seems to constitute the thin end of the wedge in various types of subsequent linguistic change.

Futhermore, he also maintains that a code can be defined as "a system used for communication between two or more parties used on any occasions."Recently, it is easy to find people who speak different languages at the same time. The phenomenon of people having more than one code (language) is called bilingualism or multilingualism (Wardhaugh, 1986a) . To show the difference of the term bilingual or multilingualism (spolsky, 1998). Defined a bilingual as "a person who has some functional ability in the second language." This may vary from a limited ability in one or more domains, to very strong command of both languages. According to 
(Rahardi, 2001), bilingualism is a situation where a speaker can use two languages as well. (Fasold, 1984). Stated that bilingualism caused by some factors, they are a) migration, b) imperialism, c) federation, and d) border area.

\section{METHOD}

The type of this research is descriptive qualitative because the writers describes the linguistic form of code mixing and the reasons of using code mixing as Instagram user which are friend with the writers.

The subject of the study is eighteen (18) Indonesian Instagram users and twenty three (23) captions. The object of this research is code mixing which is posted by the Indonesian youngster on their Instagram.

The data of the research are the status and the chats of 18 Indonesian Intagram users. The data source of the research are the post expressions in the forms of sentences in Instagram between the writers and friends and the chat between the writers with the correspondences. In collecting the data, the writers employed interview and documentations. The observation is seeking the data which contain code mixing selected by thewriters. The documentation is saving and documenting the data which taken from the observation.

In analyzing the data, the writers analyzed based on the theory of Suwito about the form of code mixing. The steps are describing the forms of code mixing, the writers uses the theory of code mixing form which was stated by Suwito.

\section{RESULTS AND DISCUSSION}

\section{Results}

According to (Suwito, 1985)based on the language element, there are several forms of code mixing. They are in the word form, phrase form, clause form, idiom form, and so on. In this case, there are some explanations about those terms below:

\section{Words}

Example: I ingin membeli sepatu.(Saya ingin membeli sepatu)

\section{Phrase}

Phrase is a group of words that forms a part of sentence.

Example: Saya pergi duluan, see you. (Saya pergi duluan, sampai jumpa.)

\section{Clause}

Clause is a component of sentence, which has a subject and predicate but, it has no endmark.

Example: Kamu seharusnya tahu bahwa health is important. (Kamu seharusnya tahu bahwa kesehatan itu penting.)

\section{Idiom}

Idiom is a phrase or clause which the meaning could not be identified directly.

Example: Saya sangat lelah fucked up. (Saya sangat lelah kacau.)

\section{Baster}

Baster is language use which is not original.

Example:Sudah waktunya kita menghindari backing-backingan.(Sudah waktunya kita menghindari mencari dukungan dalam hal negatif / premanisme.)

\section{Word Repetition}


Example: Saya bisa berbahasa Sunda little-little. ( Saya bisa berbahasa Sunda sedikitsedikit)

This writers conducted within 4 weeks, 18 people as subjects and the data taken from 23 caption Instagram and profile in instagram users. According to (Suwito, 1985) Based on the language element, there are several forms of code mixing. They are: word, phrase, Clause, Idiom, Baster, Word repetition.

The form of code mixing used by Instagram users can be classified in the following table.

Table 1. Form of Code Mixing Used by Instagram Users

\begin{tabular}{|c|c|c|c|c|c|c|c|c|}
\hline \multirow{2}{*}{ No } & \multirow[t]{2}{*}{ User } & \multirow[t]{2}{*}{ Caption } & \multicolumn{6}{|c|}{ Form of code mixing } \\
\hline & & & Word & Phrase & Clause & Idiom & Baster & $\begin{array}{l}\text { Word } \\
\text { repetation }\end{array}$ \\
\hline 1 & Dindtn & I ngupil so deep & $\mathrm{I}$ & So deep & - & - & - & - \\
\hline 2 & Erlandtg & $\begin{array}{l}\text { Sunday morning } \\
\text { hunting bubur with } \\
\text { @ adityaprabowo } s \\
\text { @liusanto21 }\end{array}$ & - & - & - & - & - & - \\
\hline 3 & aj.gum & $\begin{array}{l}150 \mathrm{~km} \text { way to go! } \mathrm{Di} \\
\text { temani supermoon }\end{array}$ & supermoon & $\begin{array}{l}150 \mathrm{~km} \\
\text { way to go }\end{array}$ & - & - & - & - \\
\hline 4 & Senopamungkass & $\begin{array}{l}\text { terilhat lebih berisi, } \\
\text { thank you jaket }\end{array}$ & & Thank you & - & - & - & - \\
\hline 5 & aaurellius & panas? Stay cool aja & - & - & - & $\begin{array}{l}\text { stay } \\
\text { cool }\end{array}$ & - & - \\
\hline 7 & Siskaylnt & $\begin{array}{l}\text { cantik ya, backround } \\
\text { nya }\end{array}$ & backround & - & - & - & - & - \\
\hline 8 & Erlandtg & $\begin{array}{l}\text { night shoot with } \\
\text { @ ziyanthoriq, foto } \\
\text { dadakan malem-malem }\end{array}$ & - & - & - & $\begin{array}{l}\text { Night } \\
\text { shoot } \\
\text { with }\end{array}$ & - & - \\
\hline 9 & adorkable750 & $\begin{array}{l}\text { supermoto gang! Yang } \\
\text { bawah coming soon. }\end{array}$ & Gang & $\begin{array}{l}\text { Coming } \\
\text { soon }\end{array}$ & - & - & - & - \\
\hline 10 & Panjimhdr & Akhirnya full-pack & - & - & - & $\begin{array}{l}\text { Full- } \\
\text { pack }\end{array}$ & - & - \\
\hline 11 & Rakhadiera & $\begin{array}{l}\text { Riding bareng } \\
\text { @ riofebriano_ }\end{array}$ & Riding & - & - & - & - & - \\
\hline 12 & Aj.gum & $\begin{array}{l}\text { Into the darkness, lagi } \\
\text { bawa tongkat lampu } \\
\text { petromax }\end{array}$ & - & - & - & - & - & - \\
\hline 13 & Yuniartyn_ & $\begin{array}{l}\text { Yaaayaa udah lama ga } \\
\text { posting foto berdua } \\
\text { bersamamu.... mengajar } \\
\text { kanku apa artinya.... }\end{array}$ & Posting & - & - & - & - & - \\
\hline 14 & Mankmerlin & $\begin{array}{l}\text { Meeting dulu diKoni } \\
\text { Jabar untuk surfing } \\
\text { Jabar yang lebih baik }\end{array}$ & $\begin{array}{l}\text { Meeting, } \\
\text { surfing }\end{array}$ & - & - & - & - & - \\
\hline 15 & Stevanus07 & Kadal classic & Classic & - & - & - & - & - \\
\hline 16 & Ziyanthoriq & $\begin{array}{l}\text { "1...2......... eh } \\
\text { telapak tangan jangan } \\
\text { gerakdulu" foto candid } \\
\text { lagidari @ okkirsndi }\end{array}$ & Candid & - & - & - & - & - \\
\hline
\end{tabular}




\begin{tabular}{|c|c|c|c|c|c|c|c|c|}
\hline 17 & Moch.ridwan27 & $\begin{array}{l}\text { Tetap bersyukur } \\
\text { dengan yang ada, next } \\
\text { year semoga lebih baik }\end{array}$ & - & Next year & - & - & - & - \\
\hline 18 & Duwiandini96 & $\begin{array}{l}\text { Finally ya liat yang ijo } \\
\text { ijo setelah tugas serta } \\
\text { rekannya yang masih } \\
\text { belum berakhir }\end{array}$ & Finally & - & - & - & - & - \\
\hline 19 & Charismasurya & $\begin{array}{l}\text { Open up your } \\
\text { muscle... dibersihin } \\
\text { dulu ya dek }\end{array}$ & - & - & $\begin{array}{l}\text { open } \\
\text { up your } \\
\text { mucsle }\end{array}$ & - & - & - \\
\hline 20 & $\begin{array}{l}\text { Seratuspersen } \\
\text { gasskeun }\end{array}$ & $\begin{array}{l}\text { Happy holiday brad... } \\
\text { jangan lupa } \\
\text { momotoran }\end{array}$ & - & $\begin{array}{l}\text { Happy } \\
\text { holiday }\end{array}$ & - & - & - & - \\
\hline 21 & Aridyawibowo & $\begin{array}{l}\text { Di } 2018 \text { woody } \\
\text { enaknya tetap stock } \\
\text { atau sedikit di nakalin } \\
\text { *racing }\end{array}$ & $\begin{array}{l}\text { Stock, } \\
\text { racing }\end{array}$ & - & - & - & - & - \\
\hline 22 & Aj.gum & $\begin{array}{l}\text { Menuju } 2018, \\
\text { terimakasih untuk } 2017 \\
\text { dan supportnya kalian } \\
\text { selama ini, jossss }\end{array}$ & support & - & - & - & - & - \\
\hline \multirow[t]{2}{*}{23} & Aj.gum & $\begin{array}{l}\text { Last satmori dadakan } \\
\text { di akhir } 2017\end{array}$ & Last & - & - & - & - & - \\
\hline & & Total & 13 & 6 & 1 & 3 & & \\
\hline
\end{tabular}

\section{Discussion}

Based on the data above,it shows that the linguistic forms which commonly used by Indonesian Instagram users are: "Word" (13), "Phrase" (6), "Idiom" (3), and "Clause" (1), We did not found Baster and Word Repetition.

The present result is in line with (Suwito, 1985) that based on the language element, there are several forms of code mixing. They are: Word, Phrase, Clause, Idiom, Baster, and Word Repetition. Moreover the reasons of using code mixing is in line with (Hockett, 1958) that the number of the use of code mixing by Indonesian youngsters is the result of bilingualism which happens in Indonesia. Likewise, (Wardhaugh, 1986b) stated that the phenomenon of bilingualism results in the occurrence of code switching and code mixing. Furthermore, multilingual country like Indonesia supports people to speak more than one language at the same time. It can lead people to do language contact as stated by (S. G. THOMASON, 2001) and (Weinreich, 1974).

According to (Wardhaugh, 2006), combining one language with other language is called code switching. Code is used by people for communication, actually be used when they devise to hide their conversation.

People speak based on where they came from and their environment. When people are in conversation they use the language that they have, generally people often use more than one language. It is very common that people develop some knowledge and ability in a second language and so become bilingual. The simplest definition of a bilingual is a person who has some functional ability in a second language. This may vary from a limited ability in one or more domains, to very strong command of both languages (Alam, 2006).

Many Indonesian people use indonesia and English at the same time. This condition is called code mixing because the condition where people use more than one language on the same topic. 
Code mixing is the use more than language that speakers or writers mix two codes or more language in discourse; the main characteristics in code mixing are relaxed situations and informal situation (Sapruto, 2013).

Recently, in line with the development of the technology of communication, language contact not only has done face to face but also by social media like Instagram. Indonesian Instagram users communicate with others by using their mother tongue language, Indonesian, and English. Indonesian people speak Javanese, Sundanese, Sumatrans, Balinese, France etc. because those are their mother tongue language. Then they speak Bahasa Indonesia because it is their national language. Last, they use English as lingua franca that show their modernity. Based on this condition, then they decided to combine all - the three languages in one communication by using code mixing.

\section{CONCLUSION}

Code mixing is the use of two languages or more by putting the linguistic elements without changing the meaning and the situation of the sentence. In this research, the instagram users applied code mixing by inserting the linguistic elements of English and Indonesian in their status. Based on the data, the linguistic forms which commonly used by Indonesian Instagram users are: "Word" (13), "Phrase" (6), "Idiom" (3), and "Clause" (1), There is no Baster and Word Repetation.The writers also found their reasons of using code mixing, they are: to practice English, to show the trend, to match with the situation, and to show their prestige.

\section{ACKNOWLEDGMENTS}

Alhamdulilahirobbil'alamin,by the grace of Allah SWT. The Writers could finally accomplish this research this paper in partial fulfillment to archieve Educational Undergraduate title.

Hereby, We would like to express our sincere gratitudde to those who have supported, motivated, helped and prayed doing and finishing this research paper, Without all of the help, we absolutely could not finish this paper, therefore, We would like to thanks to : Allah SWT Almighty Saying “ Subhanallah Walhamdulillah Walaailaaha Illahu Allahu Akbar.

\section{REFERENCES}

Alam, S. (2006). Code-mixing in Bangladesh: A case study of non-government white Collar service holders and professionals. Asian Affairs, 28.

Fasold. (1984). The sociolinguistics of society. Blackwell Publishers Oxford.

Hockett, C. F. (1958). A Course in Modern Linguistics. New York: MacMillan.

Rahardi. (2001). Sosiolinguistik Kode dan alih kode. Yogyakarta: Pustaka Pelajar Offset.

S. G. THOMASON. (2001). Concise Encyclopedia of Sociolinguistics. SocioLinguistics.

Sapruto, A. (2013). The Analysis of Indonesian-English Codes Mixing Used in " Marmut Merah Jambu " Novel State Institute of Islamic Studies ( Stain ), 1-39.

spolsky. (1998). Sociolinguistics. Oxford: Oxford University Press.

Suwito. (1985). Alih Kode, campur kode, Interferensi.

Wardhaugh, R. (1986a). An Introduction to Lingusitics. Great Britain: Hartnolls Ltd. Bodmin.

Wardhaugh, R. (1986b). An Introduction to Sociolinguistics. Oxford: Blackwell Publishing.

Wardhaugh, R. (2006). An introduction to Sociolinguistics (5th ed). Blackwell Publishing Ltd.

Weinreich, U. (1953). Languages in Contact: Findings and Problems. New York: Linguistic Circle of New York. 
Weinreich, U. (1968). Languages in Contact: Finding and Problems. Paris: Mouton Publishers. Weinreich, U. (1974). Languages in contact: Findings and problems. Netherlands. 